\section{DEVELOPMENT AND SPECIFICS OF THE CONSTRUCTION OF A LKMK 8000 LARGE CRANK PRESS \\ MILAN CECHURA}

University of West Bohemia, Faculty of Mechanical Engineering, KKS-CVTS, Plzen, Czech Republic

MARTIN VOLEJNICEK

Smeral Brno a. s., Brno, Czech Republic DOI: 10.17973/MMSJ.2019_03_2018133 cechura@kks.zcu.cz,volejnicek@smeral.cz

The article deals with the development of large forging presses for die forging. It analyses individual aspects of the development of large presses. This is followed by market analysis and a search of design solutions by individual manufacturers. Set of design recommendations has been compiled from a variety of technical solutions, according to which a press that surpasses the competition can be properly assembled.

KEYWORDS

Forging press, die forging, forming force, optimization

\section{INTRODUCTION}

More and more demands are being made for fitting a large number of large close die forgings with weight $50-60 \mathrm{~kg}$. For such large forgings, a corresponding forming force is also needed. Existing presses of $4000 \mathrm{t}(40 \mathrm{MN})$, (exceptionally 6500 $\mathrm{t}-65 \mathrm{MN}$ ) which most forges are equipped with are not strong enough for these types of forgings. That is why forging companies are demanding the purchase of larger presses to meet these increased demands.

It should be noted that the volume of production of such large forgings is limited, but the investment in a large press is considerable (for example, for presses with a forming force of $4000 \mathrm{t}$, the price is around $45-55$ million CZK, for presses with a forming force of 8000 t 130 - 160 million CZK). It can be said that the return on the large presses is relatively long, but the overall balance is more profitable.

On the other side, it should be noted that such a large press is dimensioned in such a way that with good maintenance it can last longer than small presses, often for decades. This is also due to the fact that the user is trying to maximize the production capacity of the press and therefore also includes forgings with lower force requirements $(60-80 \%$ of the nominal force). We can compare large presses to smaller presses, which are usually overloaded by the customer. These presses are usually used for a diverse assortment of small series. This is also due to the fact that forgings weighing $50 \mathrm{~kg}$ or more are not common. Typically, these are parts for trucks, earthmovers, train and air transport.

\section{MONITORING THE DESIGN OF LARGE CRANK FORGING MACHINES FROM OTHER MANUFACTURERS (F.1)}

If we want to market a modern, competitive press, we need to carry out extensive monitoring of the state of the art with other manufacturers and to find out what design innovations manufacturers are coming up with. We need to assess how these innovations have a real technical contribution to the operation of the press, their technical quality and, last but not least, their technologically demanding production and economical acceptability.

In order to obtain reliable information, a detailed analysis of the information obtained and its evaluation is required after the monitoring. The result should be the gaining of suitable, proven technical solutions that would be appropriate to apply to the new design of a machine. The following are some examples of the technical parameters of large crank forging presses.

\begin{tabular}{|c|c|c|c|c|c|c|c|c|c|}
\hline Name of & $\begin{array}{l}\text { Forming } \\
\text { force }\end{array}$ & $\begin{array}{l}\text { Number of } \\
\text { strokes }\end{array}$ & $\begin{array}{l}\text { Bed } \\
\text { size }\end{array}$ & $\begin{array}{l}\text { Ram } \\
\text { size }\end{array}$ & $\begin{array}{l}\text { Shut } \\
\text { height }\end{array}$ & $\begin{array}{l}\text { Adjustment } \\
\text { of the ram }\end{array}$ & Stroke & Input & Weight \\
\hline & $\mathrm{MN}$ & $\min ^{-1}$ & $\mathrm{~mm}$ & $\mathrm{Mm}$ & $\mathrm{mm}$ & $\mathrm{mm}$ & $\mathrm{mm}$ & kW & kg \\
\hline $\begin{array}{c}\text { Farina } \\
\text { GLF } 8000\end{array}$ & 80 & 45 & $\begin{array}{c}2000 x \\
2100\end{array}$ & $\begin{array}{c}1900 x \\
2100\end{array}$ & 1300 & 25 & 500 & 500 & 600000 \\
\hline TMP KA8549 & 80 & 40 & $\begin{array}{c}2100 x \\
2300\end{array}$ & $\begin{array}{c}1900 x \\
2350\end{array}$ & 1590 & 13 & 480 & 400 & 650000 \\
\hline $\begin{array}{c}\text { Ajax ceco } \\
8000\end{array}$ & 80 & 34 & $\begin{array}{c}1980 x \\
1930\end{array}$ & $\begin{array}{c}1880 x \\
1720\end{array}$ & 1372 & 25 & 500 & 375 & 523000 \\
\hline $\begin{array}{c}\text { SHI } \\
\text { FPA-8000 }\end{array}$ & 80 & 38 & $\begin{array}{c}1950 x \\
2150\end{array}$ & $\begin{array}{c}1870 x \\
2100\end{array}$ & 1700 & 15 & 520 & 400 & 620000 \\
\hline $\begin{array}{c}\text { NKMZ } \\
\text { KGShP-8000 }\end{array}$ & 80 & 40 & $\begin{array}{c}2100 x \\
2300\end{array}$ & $\begin{array}{c}1900 x \\
2300\end{array}$ & 1590 & 15 & 480 & 500 & 660000 \\
\hline
\end{tabular}

Figure 1. Technical parameters of large crank forging presses

For the presses mentioned above, we can see differences in technical parameters. The size of the workspace is around 2 meters from all manufacturers, and we can find similar values in the size of the lift. The number of strokes in all the presses is also related to the press power, with lower engine speeds at lower strokes.

The weight is directly dependent on the dimensions of the workspace (or even the table of the press) and is highest in the presses manufactured by TMP and NKMZ.
In terms of stand design, all presses of this size have a split anchor stand. The parts are usually sheet metal weldments. Shaft storage is left to right (in the material flow direction) to ensure proper power transfer. TMP, NKMZ and SHI have a twopoint connecting rod that reduces tilting of the ram. All manufacturers use the classic crank mechanism, apart from Farina, which uses the backdrop mechanism.

Alignment of the clamped height is carried out in TMP and SHI machines with an eccentric pin inserted into the small eye of 
the connecting rod. The Farina has a displacement directly in the gear mechanism by means of an eccentric sleeve. Ajax has an adjustment using the wedge table of the press.

There are other manufacturers and manufacturers of forging presses with a moulding force of $80 \mathrm{MN} .(3,7,10)$

SMS group offers presses with a wedge mechanism. These presses have specially designed racks due to different force distribution. Another manufacturer is the American company ERIE. This press manufacturer uses a backstop mechanism for transferring motion between the shaft and the ram. The adjustment is done by means of a wedge table with a hydraulic drive.

A new trend in industry is to design presses with torque motors. However, for this size of presses, this solution is very demanding for the power supply, and therefore not yet implemented for press sizes greater than $25 \mathrm{MN}$.

\section{SPECIFIC MACHINE DESIGN SOLUTION}

It is desirable that the new design meets the following requirements:

- Higher work area stiffness and better rake management, which guarantees higher production accuracy

- Smaller machine weight relative to the usable dimensions of the machine

- Lower energy intensity also due to smaller moving materials with less passive resistance

- Greater productivity due to the increased number of ram strokes thanks to the innovative drive.

The analysis shows a list of progressive elements in the design of large presses:

- Dual ram guide (ram with nose)

- Octagonal ram guiding

- Two-point solution of the crankshaft force transfer to the ram

- Crank the crankshaft at its centre in the third bearing and thereby reduce its load

- Using the backstop mechanism

- Spinning by loosening the preloaded anchors

- Reduced energy intensity

- Optimized frame

Based on the recommendations above for the design of a large crank forging press, a proposal was made which included all the benefits mentioned.

This proposal has been progressively developed and commented on by experts. By implementing proven design solutions, a machine design solution that meets the major requirements of today's market should be achieved.

Work on creating the prototype of this press was the subject of collaboration Smeral Brno a. s. and CVTS UWB In Pilsen. Some design solutions for this press are listed below.

Optimized rack with virtual topological optimization and energy saving measures. $(1,5,8)$

The optimization of the rack was done using virtual modelling using topological optimization, especially for optimizing the top and bottom crossbar trimming. This keeps the weight of the components down by up to $15 \%$, while maintaining the required stiffness and allowable stress.

The realizable final design of the cross members was made for both cast and welded variants. As a measure to reduce the energy intensity, an energy analysis of the drive was carried out and measures were taken to reduce its losses. $(2,6)$

The new PREDATOR belts were used for transmission from the engine to the front shaft, the shaft bearing was recalculated and modified, and the coupling-brake coupling was improved.
Theoretically, energy savings of $5-8 \%$ can be expected, but the operation will show what energy savings have been made.

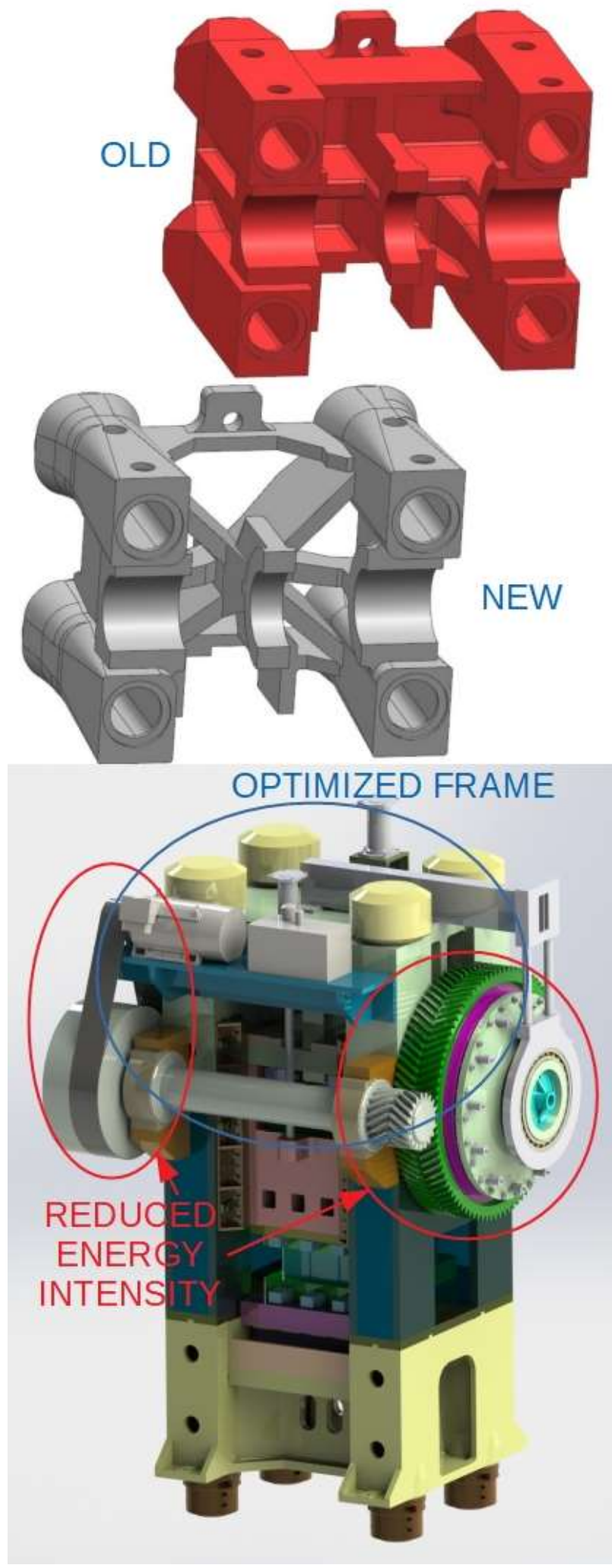

Figure 2. Optimized frame

\section{Splitting the press using anchors $(\boldsymbol{F} .2, \boldsymbol{F} .3)(4,9,11,12)$}

Occasionally, if the manufacturing discipline does not comply with the technological discipline, the rake can get wedged at the bottom position of the ram. It is a very unpleasant condition, which in the past meant the necessity of destroying the press.

Today there are patented different methods of splitting, but none of them are $100 \%$ reliable. 
Since the proposed stand is anchored and the anchors are hydraulically preloaded, the resellers have decided to use the existing hydraulic tensioners to loosen the clamping of the anchors in case of wedging, thus increasing the distance of the ram from the table and freeing the wedging. This method is reliable and operative, but expensive as well due to the price of hydraulic tensioners.

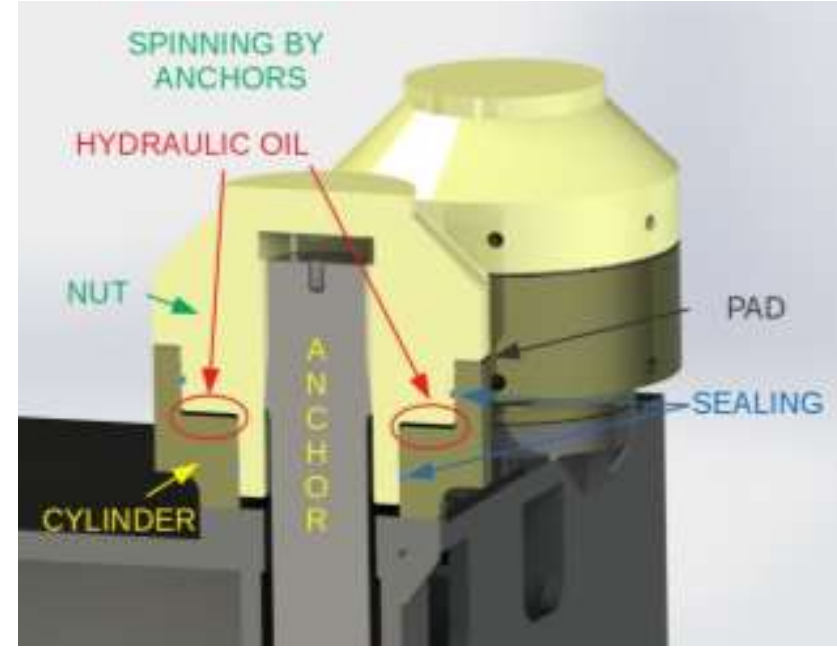

Figure 3. Spinning by anchors

\section{Octagonal ram guiding (F.4)}

Precision ram guiding in the press stand is one of the prerequisites for guaranteeing machine precision and for precise production without the use of tool guides. Workers at CVTS UWB in Pilsen therefore analysed the most widely used ram guiding and showed that the most precise way of driving is using an octagonal slide guide and hence this was used in the design.

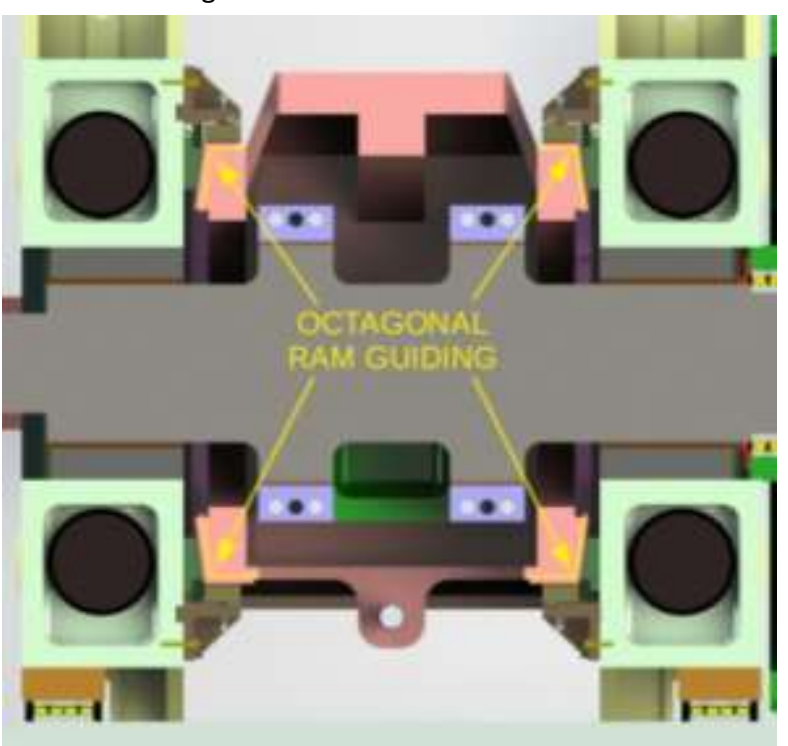

Figure 4. Octagonal ram guiding

\section{Double guiding ram (F.5)}

Since the presses are mostly of metal with a certain eccentricity acting on the press axis, the accuracy of the forging is not only given by means of the displacement of the tool, but also by the possibility of tilting the tool. It is known that the longer the guide, the less tilting of the tool, the tilt angle is less. Therefore, a double guide was used to guide the ram - one between the racks, the other on the top of the crossbar. This makes the greatest possible length of the line and thus the smallest possible tilting of the ram.

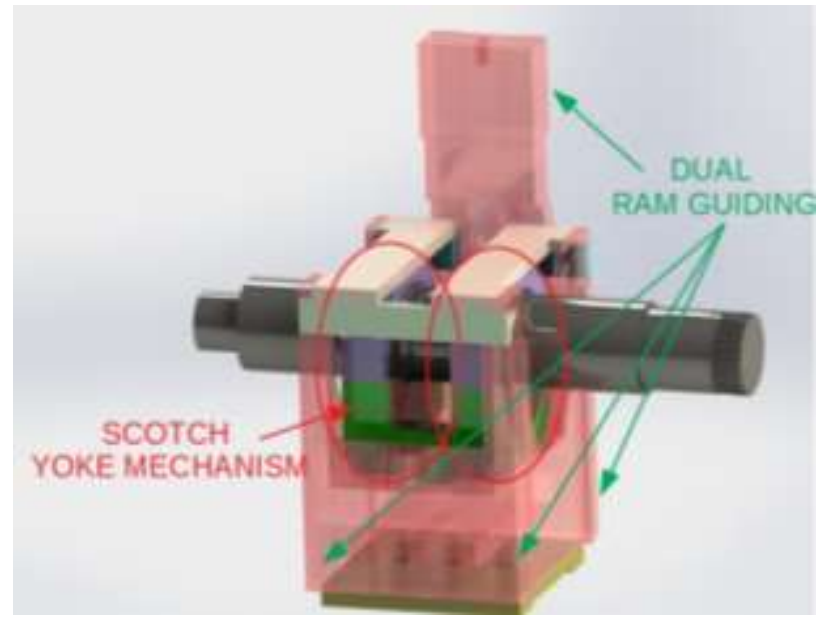

Figure 5. Dual ram guiding

\section{Scotch yoke mechanism (F.6)}

In order to have the toughest stand, it is important that the lengths of the loaded elements are as small as possible. Using the scotch yoke mechanism cuts the distance between the ram and the handle, shortens the inside of the frame, but reduces the size of the entire machine. This leads to increased rigidity of the system and also to material savings. The stiffness of the scotch yoke is larger than the connecting rod.

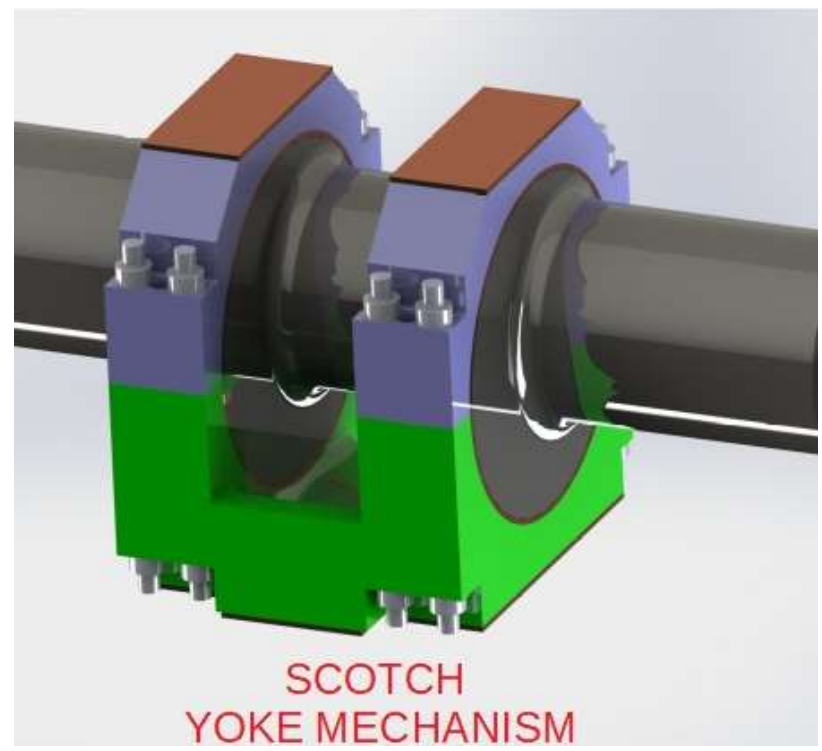

Figure 6. Scotch yoke mechanism

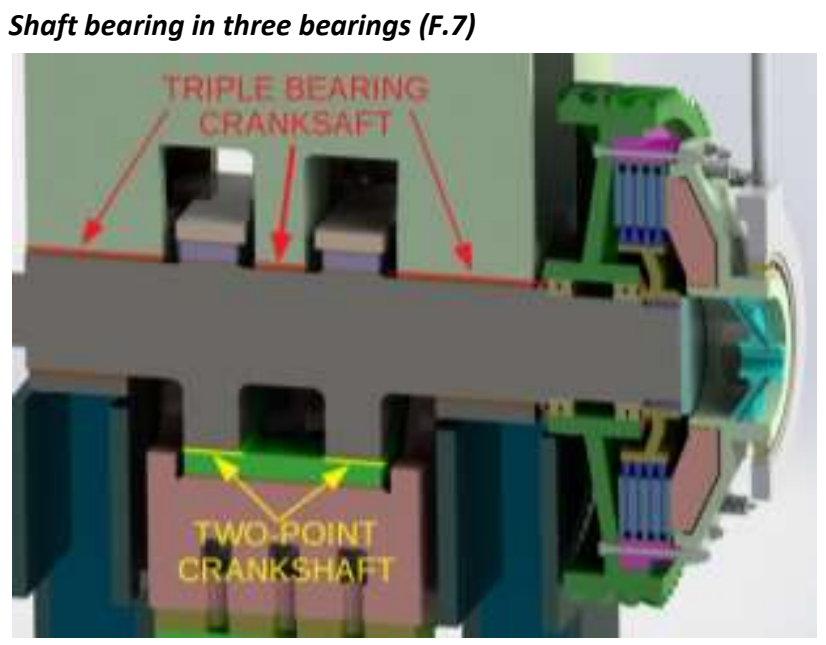

Figure 7. Triple bearing crankshaft, Two-point crankshaft 


\section{Two-point power transfer from the crankshaft (F.7)}

Because a long work table is required for the press to feed up to 5 dies in succession, it means using a long crankshaft that is less rigid. Consequently, the transfer of force to the ram was carried out at two points (using two eccentrics and a two point crankshaft, and in order for the shaft to be sufficiently stiff, it was supported by three bearings. This solution also helps to better capture the eccentric forces from the technological process.

\section{TECHNICAL CHARACTERISTICS}

\begin{tabular}{|l|c|c|}
\hline Parameter & Unites & \multicolumn{1}{l|}{ LKMK 8000} \\
\hline Nominal force & $\mathbf{M N}$ & 80 \\
\hline Stroke & $\mathbf{m m}$ & 500 \\
\hline Number of strokes & $\mathbf{1 / m i n}$ & 40 \\
\hline Table size Left to right & $\mathbf{m m}$ & $2400 \times 2400$ \\
\hline Ram size Front to back & $\mathbf{m m}$ & $2200 \times 2000$ \\
\hline Shut height & $\mathbf{m m}$ & 1250 \\
\hline Passage & $\mathbf{m m}$ & 2500 \\
\hline Number of technological & - & 3 \\
operations & & \\
\hline Ram adjustment $\quad$ Height $\mathbf{x}$ width & $\mathbf{m m}$ & $1500 \times 1400$ \\
\hline Window & $\mathbf{m m}$ & 550 \\
\hline Distance of ejector pins & $\mathbf{m m}$ & 50 \\
\hline Stroke of upper ejector & $\mathbf{m m}$ & 100 \\
\hline Stroke of lower ejector & $\mathbf{m m}$ & 10500 \\
\hline Press height above ground & $\mathbf{m m}$ & 13000 \\
\hline Overall height of press & $\mathbf{k W}$ & 530 \\
\hline Overall electric input & $\mathbf{k g}$ & 660000 \\
\hline Weight & & \\
\hline
\end{tabular}

Figure 8. Technical characteristics

\section{CONCLUSION}

Currently, CVTS and SMERAL Brno a. s. (in the project Competence Centre of Engineering Production) a machine prototype was designed.

It is assumed that if a potential candidate is found for this modern concept of an $80 \mathrm{MN}$ mechanical forging press, the machine will be made in the SMERAL Brno a. s. plant, which has also put its know-how into this project. Compared to other renowned manufacturers, this solution has many advantages:

- It can be said that a forge equipped with this machine will greatly expand its production possibilities and will be able to accurately perform even the most difficult technological processes in the world in the forging industry.

- This press will significantly increase the competitiveness not only of the presses produced by us (SMERAL Brno a. s.), but will also increase the competitiveness of our forges equipped with these machines.

And that is the fulfilment of one of the goals set by the CVTS UWB in Pilsen.

\section{CONTACTS}

Doc. Ing. Milan Cechura, CSc.

University of West Bohemia In Pilsen, Faculty of Mechanical Engineering, KKS-CVTS

Univerzitni 22, Plzen, 306 14, Czech Republic

+420 37763 8256, cechura@kks.zcu.cz, www.cvts.zcu.cz

\section{ACKNOWLEDGMENTS}

This article was created with the financial support of MSMT CZ 02.1.01/0.0/0.0/16-026/0008404

\section{REFERENCES}

[BELE 2017] BELE, M., BLECHA, P., CECHURA, M., GROSEK, F., HLAVAC, J., CHVAL, Z., KUBEC, V., RAZ, K., SMOLIK, J., STANEK, J., TOMAN, P., VOLEJNICEK, M., ZAHALKA, M. DV\#11 Development and innovations of new and existing forming machines (In Czech). TACR, 2017.

[BELE 2017] BELE, M., HLAVAC, J. Evaluation of the energy intensity of forming machines compared to approaches in other industries. Vienna: DAAAM International, 2017. s. 1057-1064. ISBN: 978-3-902734-11-2 , ISSN: 1726-9679

[CECHURA 2009] CECHURA, M., CIREK, M., HLAVAC, J., KUBEC, V. Comparison of the pre-loaded and ordinary monolithic welded mechanical press stand (In Czech). In Technologia 2009. Bratislava: STU, 2009. s. 331-334. ISBN: 978-80-227-3135-5

[CECHURA 2010] CECHURA, M., CIREK, M., HLAVAC, J., CHVAL, Z. Structural design of the LZK 5000 splitted stand, including anchors and hydraulic tightener (In Czech). Plzen : 2010. S. 68.

[CECHURA 2017] CECHURA, M., HLAVAC, J. New structural design of the crank forging press with nominal force of $80 \mathrm{MN}$ (In Czech). Kovarenstvi, roc. 60, Kveten 2017, s. 93-96. ISSN: 1213-9289

[CHVAL 2015] CHVAL, Z., CECHURA, M. Monitoring extremely stressed points on stands of forging presses. In Procedia Engineering. Viden: DAAAM International Vienna, 2015. s. $841-$ 846. ISBN: 978-3-901509-99-5 , ISSN: 1877-7058

[CHVAL 2016] CHVAL, Z., CECHURA, M. Design of mechanical forging press with maximal force in side cavity. MM Science Journal, roc. 2016, November, s. 1358-1361. ISSN: 1803-1269

[CHVAL 2016] CHVAL, Z., RAZ, K., CECHURA, M. Analysis of Stress Distribution in the Forging Press. Vienna: Danube Adria Association for Automation and Manufacturing, DAAAM, 2016. s. 488-493. ISBN: 978-3-902734-07-5 , ISSN: 1726-9679

[DANG-VAN 1993] DANG-VAN, K. Macro-Micro Approach in High-Cycle Multiaxial Fatigue. Advances in Multiaxial. 1993, Sv. ASTM STP 1191, stránky 120-130.

[HLAVAC 2006] HLAVAC, J., CECHURA, M., CIREK, M. Extrusion presses frame design. In Proceedings of the 5th DAAAM international conference on Advanced technologies for developing countries. Rijeka: University of Rijeka, 2006. s. 5558. ISBN: 953-6326-45-0

[HLAVAC 2017] HLAVAC, J., CECHURA, M., KUBEC, V., ZAHALKA, $M$. An analysis of the method of releasing the cranked crank press (In Czech). Kovarenstvi, roc. 60, Kveten 2017, s. 101-104. ISSN: 1213-9289

[TOMAN 2017] TOMAN, P., VOLEJNICEK, M.: New engineering trends of forming machines Smeral Brno company (in Czech). Kovarenstvi, roc. 60, Kveten 2017, s. 97-101. ISSN: 1213-9289

Ing. Martin Volejnicek

Smeral Brno a. s.

Krenova 65c, 65825 Brno, Czech Republic

+420 532167 328, +420 721952 505, volejnicek@smeral.cz www.smeral.cz 